\title{
Children's Religious Coping Scale: Adaptation and Psychometric Properties ${ }^{1}$
}

\author{
Miriam Raquel Wachholz Strelhow ${ }^{2}$ \\ Universidade Federal do Rio Grande do \\ Sul, Porto Alegre-RS, Brazil
}

\author{
Jorge Castellá Sarriera \\ Universidade Federal do Rio Grande do \\ Sul, Porto Alegre-RS, Brazil
}

\author{
Livia Maria Bedin \\ Universidade Federal do Rio Grande do \\ Sul, Porto Alegre-RS, Brazil
}

\begin{abstract}
Religious coping refers to the use of strategies related to religious faith in coping with stressful situations. This study presents the adaptation of the Children's Religious Coping scale (CRC) for Brazilian children and verifies its psychometric properties. Participants are 1,612 children $(54.71 \%$ girls) between 8 and 13 years old $(M=10.19, S D=1.47)$. Principal component and confirmatory factor analyses indicated that the CRC was composed of two dimensions: Positive Religious Coping, with 17 items in three factors (Belief in God's support, Seeking the religious institution, Intercession), and Negative Religious Coping, consisting of 11 items in three factors (Dissatisfaction with God or others, Negative reappraisal of meaning, Punishing reappraisal). The instrument showed adequate reliability, multigroup confirmatory factor analyses indicated that the items factor weights are similar by sex. The scale showed good fit indices for this sample, demonstrating that it can be a promising instrument for future research.
\end{abstract}

Keywords: stress, religiosity, psychometrics, factor analysis

\section{Escala de Coping Religioso para Crianças: Adaptação e Propriedades Psicométricas}

\begin{abstract}
Resumo: Coping religioso se refere ao uso de estratégias relacionadas à fé religiosa para lidar com situações estressantes. Esse estudo apresenta a adaptação da escala de Coping Religioso para Crianças (CRC) para crianças brasileiras e verifica suas propriedades psicométricas. Participaram 1.612 crianças $(54,71 \%$ meninas) entre 8 e 13 anos $(M=10,19, D P=1,47)$. Análises de componentes principais e fatoriais confirmatórias indicaram que a CRC é composta por duas dimensões: Coping Religioso Positivo, com 17 itens em três fatores (Crença no suporte de Deus, Busca à instituição religiosa, Intercessão), e Coping Religioso Negativo, composto por 11 itens em três fatores (Descontentamento com Deus ou com outros, Reavaliação negativa do significado, Reavaliação de punição). O instrumento apresentou confiabilidade adequada. Análises fatoriais multigrupo indicaram que as cargas fatoriais dos itens são semelhantes por sexo. A escala apresentou bons índices de ajuste para essa amostra, demonstrando ser um instrumento promissor para futuras pesquisas.
\end{abstract}

Palavras-chave: stress, religiosidade, psicometria, análise fatorial

\section{Escala de Afrontamiento Religioso para Niños: Adaptación y Propiedades Psicométricas}

\begin{abstract}
Resumen: Coping religioso se refiere a la utilización de estrategias relacionadas a la fe religiosa para hacer frente a situaciones de estrés. Este estudio presenta la adaptación de la escala de Afrontamiento Religioso para Niños (CRC) y verifica sus propiedades psicométricas para brasileños. Participaron 1.612 niños (un $54.71 \%$ niñas) entre 8 y 13 años $(M=10.19, D E=1.47)$. Análisis de componentes principales y factoriales confirmatorios indicaron que la CRC está compuesta de dos dimensiones: Afrontamiento religioso positivo, con 17 ítems en tres factores (Creencia en apoyo de Dios, Busca por establecimiento religioso, Intercesión) y Afrontamiento religioso negativo, compuesta de 11 ítems en tres factores (Insatisfacción con Dios, Revaluación negativa de significado, Revaluación de punición). El instrumento presentó fiabilidad adecuada, análisis confirmatorios multigrupo indicaron que los pesos factoriales de los ítems son similares por sexo. La escala presentó buenos índices de ajuste, y es un instrumento promisor para estudios futuros.
\end{abstract}

Palabras clave: estrés, religiosidad, psicometría, análisis factorial

\footnotetext{
${ }^{1}$ Paper derived from the Master's thesis conducted by the primary author, Miriam Raquel Wachholz Strelhow, under the supervision of Jorge Castellá Sarriera, defended in 2013, for the Graduate Program in Psychology at the Universidade Federal do Rio Grande do Sul.

Financial Support: National Council for Scientific and Techological Development - CNPq/ 133359/2011-5
}

\footnotetext{
${ }^{2}$ Correspondence address: Miriam Raquel Wachholz Strelhow. Universidade Federal do Rio Grande do Sul, Instituto de Psicologia, Departamento de Psicologia do Desenvolvimento e da Personalidade. Rua Ramiro Barcelos, 2600. CEP 90035003. Porto Alegre-RS, Brasil. E-mail: raquelwch@gmail.com
} 
Children need to manage everyday situations that often cause stress and require coping skills. Studies indicate that these situations differ from those experienced by adults, referring to conflicts with peers, conflicts with and between parents, school situations, and everyday tasks, among other stressors (Ryan-Wenger, Sharrer, \& Campbell, 2005). When facing difficult situations, the way people deal with stress makes a difference in human functioning. Thus, studies have investigated coping strategies, which are the set of strategies used by people to adapt to adverse circumstances (Lazarus \& Folkman, 1987).

Some people turn to their religious faith in adverse moments. In religious coping, people use their beliefs and behaviors related to religion to prevent or relieve the negative consequences of life situations, and to facilitate the resolution of problems (Pargament, 1997). According to Pargament, Koenig, and Perez (2000), religious coping has five central functions: the search for meaning or purpose; the search for control of situations; the search for comfort; intimacy and social integration; and life transformation. Scholars have done research that groups religious strategies into two categories: positive religious coping and negative religious coping (Pargament, Smith, Koenig, \& Perez, 1998).

Positive religious coping includes strategies that provide beneficial effects to the one who practices it, involving an expression of spirituality, a secure relationship with God, and a spiritual connection with others. In general, these strategies are related to benevolent outcomes, including fewer symptoms of psychological distress, and psychological and spiritual growth. Negative religious coping strategies involve those with an insecure relationship with God, tension between members of a religious community, a pessimistic view of the world and spiritual discomfort. These strategies have generally presented a non-adaptive character (Panzini \& Bandeira, 2007; Pargament et al., 1998).

There are a considerable number of studies regarding religious coping with adults (Pargament, 1997; Pargament et al., 2000) that demonstrate that religious coping significantly predicts outcomes, even when controlling for general coping measures (Pargament, 1997). In spite of the clear importance of religious coping, there is only an incipient, though increasing, interest in the investigation of this subject with youth (Al-Hadethe, Hunt, Thomas, \& Al-Qaysi, 2014; Cotton, McGrady, \& Rosenthal, 2010; Noh, Chang, Jang, Lee, \& Lee, 2015; Renani, Hajinejad, Idani, \& Ravanipour, 2014; Reynolds, Mrug, Hensler, Guion, \& Madan-Swain, 2014).

In an extensive literature review concerning religious coping with children and adolescents, Mahoney, Pendleton, and Ihrke (2006) found only 14 studies. Most of them were descriptive, using small samples and non-standardized measures. Nevertheless, as Bjorck, Braese, Tadie, and Gililland (2010) state, these studies support the relevance of religious coping for youth, and make the need for a reliable and valid measure of this construct even clearer. Similarly, in the last ten years, only a few researchers have assessed religious coping with children (Benore, Pargament, \& Pendleton, 2008; Cotton, Grossoehm, \& McGrady, 2012; Pendleton, Cavalli, Pargament, \& Nasr, 2002; Renani et al., 2014).
In one qualitative study, Pendleton et al. (2002) investigated the use of religious coping by children with cystic fibrosis. Children reported different religious and spiritual coping strategies that were almost always associated with adaptive health outcomes. Also, Cotton et al. (2012) investigated the use of religious coping strategies by children with sickle cell disease, concluding that children used their faith to gain control, make meaning, and find comfort. Renani et al. (2014) interviewed nine children with moderate to severe asthma and their parents. Participants referred to their religious belief as important in coping with their asthmatic condition and improving it.

In a quantitative study, Benore et al. (2008) evaluated the relationship between positive and negative religious coping strategies and adjustment among children and adolescents hospitalized for asthma. To test the relationship between religious coping and adjustment, the authors controlled for six variables (age, gender, religious importance, perceived overall health, control of asthma, and challenge of asthma) in the regression models. Through hierarchical regression analyses, they tested whether religious coping strategies accounted for a unique portion of variance in adjustment during hospitalization and at the one-month follow-up. The results showed that after controlling for selected variables, religious coping significantly predicted variance in asthmarelated quality of life, depression, and anxiety during hospitalization.

According to Bjorck et al. (2010), assessing religious coping is a relatively recent endeavor, even for research with adults. Compas, Connor-Smith, Saltzman, Thomsen, and Wadsworth (2001) state that the limited clarity regarding the conceptualization and definition of coping makes it difficult to validate and generalize some results. Also, it is difficult to have scales that can include all the specific domains that are theoretically interesting (Carver, Scheier, \& Weintraub, 1989). Thus, it is assumed that there may be an overlap of the items in terms of theoretical significance when seeking to evaluate the many possible strategies.

The Children's Religious Coping Scale (CRC) is an instrument specifically designed for children, taken from the RCOPE religious coping scale for adults (Pargament et al., 2000) and from a qualitative study on children's religious coping strategies carried out by Pendleton et al. (2002). The RCOPE adaptation makes it possible to reduce its complexity for children and to include strategies used only by them, which are not present in the instrument for adults (Benore et al., 2008). Considering the importance of religious coping for children and the lack of studies in this area, this article presents an adaptation of the Children's Religious Coping scale (CRC) for Brazilian children and verifies its psychometric properties in the studied sample.

\section{Method}

This study was divided into two phases: Phase 1, the adaptation process and Phase 2, the psychometric properties evaluation. The adaptation process of the CRC Scale was performed in accordance with the six stages of instruments 
adaptation proposed by Borsa, Damásio, and Bandeira (2012): (1) instrument translation from the original language into the target language by at least two independent bilingual translators; (2) synthesis of the translated version; (3) a synthesis evaluation by experts; (4) instrument evaluation by the target population; (5) back translation; and (6) a pilot study. In Phase 2, the evaluation of some psychometric properties of the CRC scale were performed through Principal components analysis, reliability analysis, confirmatory factor analyses and multigroup analysis by sex.

\section{Phase 1: CRC Scale Adaptation}

Initially, two independent translators fluent in English translated the scale into Brazilian Portuguese. Then, two psychologists prepared and reviewed a synthesis of the comparison of the two initial versions with the aim of finding the best semantic and conceptual equivalence for each item, by comparison with the original version.

For a semantic validation, the scale translated into Portuguese was applied to a convenience sample of 22 children (8 to 12 years old, of both sexes). Children completed the instrument individually, pointing out to researchers their doubts regarding the understanding of items, in order to assess possible difficulties in completing the questionnaire. Some specific religious terms were inserted into or modified on the scale, to make it more inclusive to different religious denominations/beliefs. For example, the item "I read the Bible" was changed to "I read the holy book of my religion (for example, the Bible)", and the following sentence was added to the instruction for filling in the scale: "When reading the phrases, understand the word God according to what you believe".

After the semantic validation, a bilingual translator performed a back translation, and this version in English was compared with the original scale in order to make sure that each item retained its original meaning, despite the changes made. The version resulting from this process was submitted to a pilot application with 74 children of both sexes, aged between 7 and 13 years old $(M=9.67, S D=1.30)$, students from 3rd to 7 th grades from an elementary school.

\section{Phase 2: CRC Scale Psychometric Properties}

Participants. The participants were 1,612 children between the ages of 8 and 13 years old $(M=10.19, S D=$ 1.47), with $54.71 \%$ being girls. Children were in the 3rd to 7 th grade from public $(54.59 \%)$ and private $(45.59 \%)$ schools, in the metropolitan area of Porto Alegre (62.34\%) and four other cities of the State of Rio Grande do Sul: Santa Cruz do Sul (9.74\%), Rio Grande (8.31\%), Passo Fundo (14.33\%) and Santa Maria (5.27\%). Regarding religious identification, $73.45 \%$ of the children reported having one religion, $5.77 \%$ more than one, and $13.40 \%$ said they had no religion. Participants who reported having one or more than one religion identified themselves as Catholic (52.05\%), Evangelical (15.57\%), Spiritist (8.50\%), Protestant (4.16\%), from African-Brazilian religions (3.35\%) and others (3.10\%).

\section{Instruments}

The instruments used were a sociodemographic questionnaire (age, gender, school year, religion) and the CRC scale adapted to Brazilian Portuguese. The CRC scale was initially created for children with chronic illnesses, Dupre (2008) adapted the CRC and used it in a study with children in regular schools, in order to investigate the religious coping strategies used in everyday situations. Dupre also found a two-factor model (Positive Religious Coping, $\alpha=.95$, and Negative Religious Coping, $\alpha=.86$ ).

The adapted CRC scale was composed of 32 items, with the following instruction: "The statements below represent some of the ways people deal with problems or situations that bring difficulties or concerns. For example, problems in the family, with friends or at school. In general, when you have a problem, how often do you think or do the following?". Responses were marked on a frequency scale of five points (0-4) from "never" to "almost always".

\section{Procedure}

Data collection. The data collection was conducted in schools that were contacted based on convenience, taking into account a balance between public and private schools in each participating city. The schools were selected according to the criteria of offering elementary education and agreeing to participate in the study by signing the Institutional Consent Form. The children responded to the instrument collectively in the classroom under the guidance of two researchers. For 3 rd graders, one of the researchers responsible for applying the questionnaire read the questions aloud in the class to make it easier for the children to understand. In the other classes, the researcher gave initial instructions and the children read the questionnaire by themselves.

Data analysis. Descriptive analyses of the Religious Coping Scale items were performed. The missing data was imputed by regression, considering that there was less than $5 \%$ missing. After examining the data, the sample was randomly divided into two subgroups to verify the factor structure of the scale. Through $t$ test analyses, it was verified that there were no significant differences between the two groups regarding school type, sex, age or religious affiliation $(p>0,05)$. Principal components analysis (PCA) and reliability analysis were performed with half of the sample $(n=771)$ using the SPSS 18 software. PCA were performed through Kaiser normalization and with direct oblimin rotation, considering that the scale factors are correlated. The assumptions for the analysis were met $(K M O=.94$, and Bartlett's test, $p<.001)$.

Confirmatory factor analyses (CFA) and multigroup analysis by sex were performed with the second half of the sample $(n=841)$ using the Amos 21 software. Through CFA, the adequacy of the scale was assessed, considering some adjustment indicators: Chi-square, CFI (Comparative Fit Index), TLI (Tucker and Lewis Index), RMSEA (Root Mean Squared Error of Approximation) and SRMR (Standardized Root Mean Squared Residual). For these indices, the literature indicates as acceptable values those above .90 for the CFI and 
TLI, with best values close to 1. For RMSEA and SRMR, values below .08 are indicated as optimal (Hair, Black, Babin, Anderson, \& Tatham, 2009).

Through multigroup CFA, two models are tested. In the first, the parameters are freely estimated for each group, with only the plausibility of the structure tested (the model adequacy for each group). In the second model, the factor loadings are constrained to be equal between groups, assessing whether the items have the same meaning for them. The comparative fit indices between the models were taken into account, considering the difference between the CFI models. The difference between the CFI $(\triangle C F I)$ should not be greater than .01 , and thus, the overall results indicate the viability of restricting the factor loadings to be the same in different groups (Milfont \& Fischer, 2010).

\section{Ethical Considerations}

At all stages of the research, ethical procedures were respected in accordance with the criteria for Ethics in Human Research, Resolution 196/96 of the Brazilian National Health Council. An informed consent form was developed, considering the ethical and legal aspects, and parents' consent was required for each child. The Research Ethics Committee of the Institute of Psychology of the University approved the research project.

\section{Results}

\section{Phase 1: CRC Scale Adaptation}

A reliability analysis was carried out from the pilot data, and it was noted that the exclusion of two items of the negative religious coping dimension ("I just let God take care of me and I do nothing", and "I think people did not pray for me") increased Cronbach's alpha from .67 to .72 , so it was decided to exclude these two items. The final version of the scale was composed of 32 items $(\alpha=.81)$ : 20 items of positive coping $(\alpha=.91)$ and 12 items of negative coping $(\alpha=.72)$.

After the analysis of these data, it was decided to change the item "I do not think about God much" to "I think about God very much". Although the item has been used by other authors as belonging to the NRC dimension (Benore et al., 2008; Dupre, 2008), in its original composition it has a meaning similar to other items which were considered neutral (example, I do not turn to God, I think about other things). It is understood that when the child states that when facing a problem, she/he "thinks much about God," the sentence contains a sense of seeking support, to turn to God.

\section{Phase 2: CRC Scale Psychometric Properties}

CRC scale principal components analysis. A PCA of the 32 items of the CRC scale was performed $(n=771)$, and from the Kaiser normalization, a solution of five factors was found, two related to PRC and three to NRC, explaining 51.9\% of the variance. However, by adopting a criterion of factors with eigenvalues equal to or greater than two, a two-factor solution was obtained, explaining $39.63 \%$ of the variance, with a Cronbach's alpha of .90 . The two-factor solution proved to be adequate according to the literature (Benore et al., 2008; Pargament et al., 1998), since it empirically demonstrates the differentiation between the two dimensions of religious coping (PRC and NRC). Therefore, PCA were performed separately for the PRC dimension $(\alpha=.92)$ and NRC dimension $(\alpha=.80)$, with the aim of specifying which types of strategies compose each dimension. Similar steps were performed for the Spiritual Religious Coping Scale in the study by Panzini and Bandeira (2005).

In the two-factor solution, the items were divided as expected, except for the item "I think that God gave some of us problems for a reason". According to previous studies, this belonged to the PRC dimension. However, the children's evaluation that God has given them problems for some specific reason may be linked with the outcome of a negative consequence, as well as other items that belong to the dimension of NRC. Therefore, it was decided to keep the item in the NRC dimension, based on the evidence of the empirical data.

PRC dimension principal components analysis. After the division of the items into two dimensions, a PCA of the PRC dimension (20 items) was performed and a three-factor solution was found, explaining $55.04 \%$ of the variance. The factor structure and the factor loadings of each item are shown in Table 1. The items that presented the lowest factor loadings were items 8 and 17. These two items also have presented cross-factor loadings in more than one factor.

Table 1

Principal Components Analysis of the Positive Religious Coping Dimension $(n=771)$

Component

1

2

3

Factor 1: Belief in God's support

18. I think that God will help me get through it.

22. I think about God always being with me.

02. I think God is watching over me.

15. I think about God very much.

10. I try to see how God might be making me a better person. 


\begin{tabular}{|c|c|c|c|}
\hline & \multicolumn{3}{|c|}{ Component } \\
\hline & 1 & 2 & 3 \\
\hline 24. I try to get to know God better. & .615 & & \\
\hline 20. I tell God to help me and He does it. & .596 & & \\
\hline 12. I pray to God to take away my problems. & .588 & & .360 \\
\hline 32. I think God is calming me. & .585 & & \\
\hline 04. I thank God for the problem not being worse. & .563 & & \\
\hline 06. I ask God to help me understand it. & .536 & & .363 \\
\hline 01. I pray that God will make me feel better. & .436 & & .333 \\
\hline 08. I talk with God and He tells me how to feel better. & .340 & .344 & \\
\hline 17. I think about what my faith says about fixing problems. & .322 & & .317 \\
\hline \multicolumn{4}{|l|}{ Factor 2: Seeking the religious institution } \\
\hline 03. I talk to the leader of my religion (for example, minister/priest/rabbi). & & .789 & \\
\hline 26. I go to church/temple/synagogue. & & .786 & \\
\hline 27. I read the holy book of my religion (for example, the Bible). & & .767 & \\
\hline \multicolumn{4}{|l|}{ Factor 3: Intercession } \\
\hline 11. I ask others to pray for me. & & & .788 \\
\hline 16. I think my family and friends are praying for me. & & & .638 \\
\hline 21. I pray that I do not die. & & & .603 \\
\hline Reliability (Cronbach’s alpha) & .92 & .76 & .64 \\
\hline Explained variance $(\%)$ & 42.12 & 7.39 & 5.53 \\
\hline
\end{tabular}

Factor 1 was termed "Belief in God's support", because it includes behaviors and thoughts related to belief in and search for God's support. This factor was composed of 14 items, and obtained a Cronbach's alpha of .92. Although the item "I talk with God and He tells me how to feel better" also presented a factor loading very similar in the second factor, it was decided to keep it with the first factor based on its meaning. The second factor includes three items referring to the search for a religious institution. The first refers to the search for support through a religious leader, and the other two refer to a religious ritual. In this composition, the factor obtained a Cronbach's alpha of .76. The third factor called "Intercession" because it contains items that mention the search for the intercession of others, as well as individual intercession. This factor was the one that obtained the lowest alpha $(\alpha=.64)$.

NRC dimension principal components analysis. The PCA of the NRC dimension indicated a three-factor solution, explaining $51.84 \%$ of the variance, as shown in Table 2 . Three items had factor loadings greater than .30 on two factors (items 14, 23, and 28); however, it was decided to keep them with the factors in which they had a higher load.

Table 2

Principal Components Analysis of the Negative Religious Coping Dimension ( $n=771)$

\begin{tabular}{lc}
\hline & Component \\
& \multicolumn{1}{c}{2} \\
\hline Factor 1: Discontent with God or others & 3 \\
19. I stop believing in God. & .799 \\
29. I think God does not love me. & .714 \\
09. I get angry at God. & .631 \\
25. I think God cannot help me. & .568 \\
23. I think people at church/temple/synagogue blame me for it. & .422 \\
Factor 2: Negative reappraisal of meaning & .321 \\
05. I wonder why God lets this happen to me. & \\
\end{tabular}


07. I tell myself God tried to help me but it didn't work.

.684

13. I wonder if God is mad at me.

14. I think that God gave some of us problems for a reason.

Factor 3: Punishing reappraisal

30. I think that evil (for example, the devil) did this to me.

31. I think God did this because I was a bad person.

28. I think that maybe God is punishing me.

The first factor was termed "Discontent with God or others", since it indicates a negative relationship with God and with people of a religious institution. It was composed of five items, and obtained a Cronbach's alpha of .71. The second factor was composed of four items related to a negative reappraisal of the problem, indicating a questioning of the situation faced, and obtained an alpha of .64; it was termed "Negative reappraisal of meaning". The third factor, "Punishing reappraisal", includes items that refer to the problem as a punishment caused by God or evil, and obtained the lowest alpha $(\alpha=.62)$.

Confirmatory factor analyses. The model was tested ( $n=841)$ according to the original scale, in which two factors relating to $\mathrm{PRC}$ and $\mathrm{NRC}$ dimensions were set (Model 1).
Initially, item 14 was retained in the PRC dimension, as recommended by the authors (Benore et al., 2008). However, the need to move item 14 to the NRC dimension was confirmed, as already indicated in the PCA. Initial analysis of this model showed bad fit indices, so it was decided to remove items 01 , 02, and 32, which belonged to the factor "Belief in God's support" (PRC), and item 14 of the factor "Negative reappraisal of meaning", because they had high covariances with other items. When they were removed, there was an improvement in the model fit (Table 3). Additions of 14 covariances among the errors were performed for the final model with two factors (Figure 1, left), as indicated by the modification indices. In this new composition, the Cronbach's alphas of the two factors were .91 for the PRC, and .80 for the NRC.
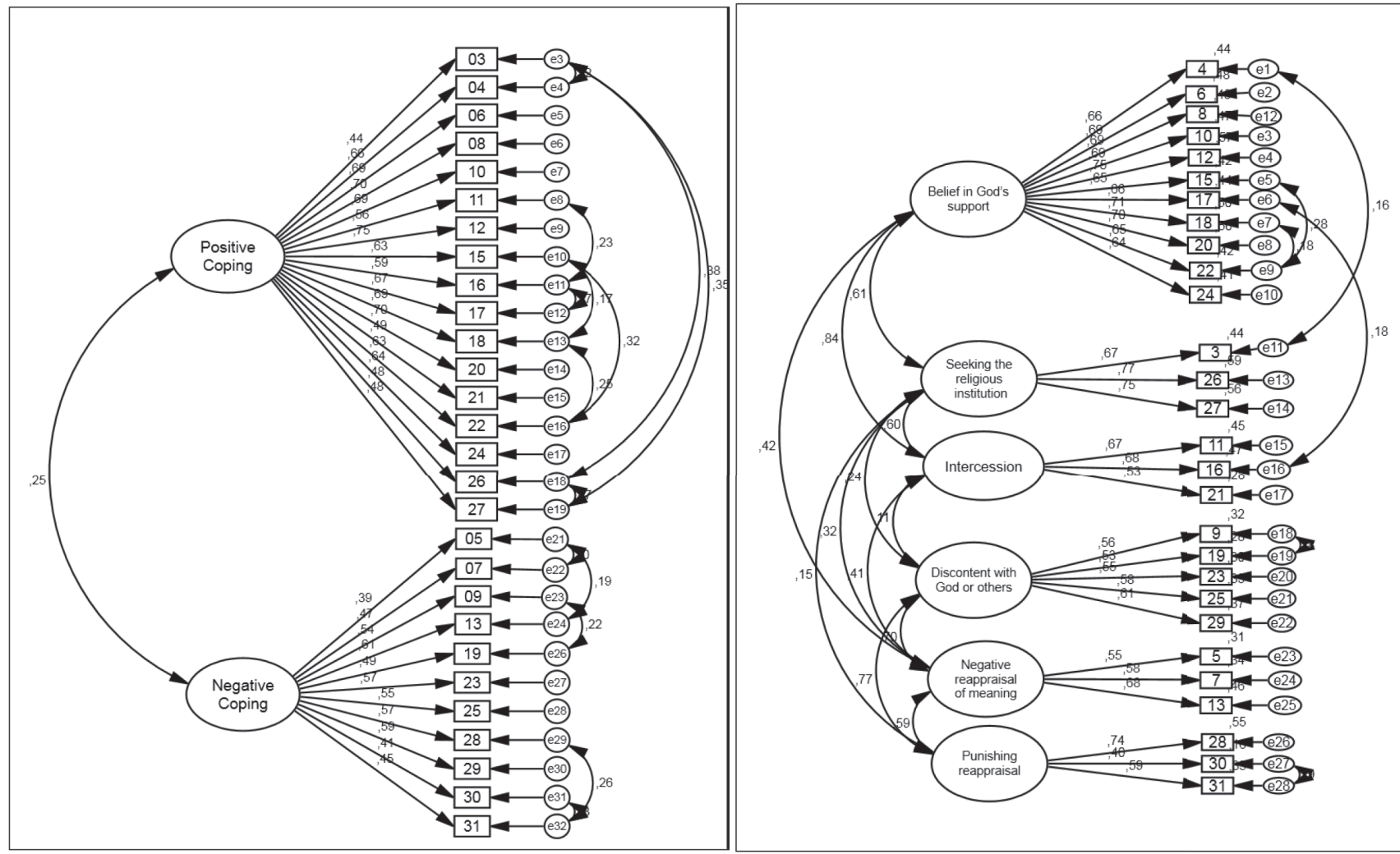

Figure 1. CRC Scale Models Composed of Two and Six Factors, standardized weights 
A second model tested was composed of six factors (Model 2), three PRC and three NRC factors. In this model, items $01,02,32$ and 14 were also removed because they presented the lowest factor loadings. When removed, there was an improvement in model fit. For the final model 2 (Figure 1 , right), six error covariances were added, as indicated by the modification indices, reaching a CFI of .93. After the removal of these items, there were small changes in Cronbach's alphas of the factors "Belief in God's support" $(\alpha=.90)$, and
"Negative reappraisal of meaning" $(\alpha=.63)$.

Table 3 presents the fit indices for the two models analyzed before and after the exclusion of the items and the additions of the covariance among the errors. The data indicated that both models, after the addition of the covariances among the errors, showed adequate fit indices, but model 2 appeared to represent the data slightly better than model 1 . Table 4 presents the factor loadings of the 28 items that compose model 2 of the CRC scale, which ranged between .40 and .75 .

Table 3

Fit Indices for the Models of Confirmatory Factor Analyses $(n=841)$

\begin{tabular}{|c|c|c|c|c|c|c|c|}
\hline & $X^{2}$ & $d f$ & $p$ & TLI & CFI & RMSEA (C.I.) & SRMR \\
\hline 1. Model 1 with 32 items in two dimensions & 2224.91 & 463 & $<.001$ & .811 & .824 & $.067(.065-.070)$ & .079 \\
\hline 2. Model 1 with 28 items in two dimensions & 1779.51 & 349 & $<.001$ & .816 & .830 & $.070(.067-.073)$ & .080 \\
\hline $\begin{array}{l}\text { 3. Model } 1 \text { with } 28 \text { items in two dimensions, and } 14 \\
\text { covariances among errors }\end{array}$ & 1025.19 & 335 & $<.001$ & .907 & .918 & $.050(.046-.053)$ & .073 \\
\hline 1. Model 2, with 32 items in six factors & 1632.24 & 450 & $<.001$ & .870 & .882 & $.056(.053-.059)$ & .064 \\
\hline 2. Model 2, with 28 items in six factors & 1250.00 & 336 & $<.001$ & .878 & .891 & $.057(.054-.060)$ & .065 \\
\hline $\begin{array}{l}\text { 3. Model 2, with } 28 \text { items in six factors and six } \\
\text { covariances among errors }\end{array}$ & 904.05 & 332 & $<.001$ & .922 & .932 & $.045(.042-.049)$ & .061 \\
\hline
\end{tabular}

\section{Table 4}

Standardized Factor Weights of the Religious Coping Scale for the Model Composed of Six Factors $(n=841)$

\begin{tabular}{|c|c|c|}
\hline Item & Factor & Factor Loading \\
\hline 04 & \multirow{11}{*}{ Belief in God's support } & .660 \\
\hline 06 & & .692 \\
\hline 08 & & .695 \\
\hline 10 & & .689 \\
\hline 12 & & .754 \\
\hline 15 & & .647 \\
\hline 17 & & .662 \\
\hline 18 & & .710 \\
\hline 20 & & .704 \\
\hline 22 & & .650 \\
\hline 24 & & .639 \\
\hline 03 & \multirow{3}{*}{ Seeking the religious institution } & .590 \\
\hline 26 & & .574 \\
\hline 27 & & .584 \\
\hline 11 & \multirow{3}{*}{ Intercession } & .671 \\
\hline 16 & & .684 \\
\hline 21 & & .528 \\
\hline 9 & \multirow{5}{*}{ Discontent with God or others } & .562 \\
\hline 19 & & .531 \\
\hline 23 & & .550 \\
\hline 25 & & .577 \\
\hline 29 & & .609 \\
\hline 05 & \multirow{3}{*}{ Negative reappraisal of meaning } & .553 \\
\hline 07 & & .585 \\
\hline 13 & & .682 \\
\hline 28 & \multirow{3}{*}{ Punishing reappraisal } & .739 \\
\hline 30 & & .402 \\
\hline 31 & & .588 \\
\hline
\end{tabular}

A multigroup CFA was also performed, considering the CRC scale with six factors, to verify the equivalence of parameters for sex. The multigroup analyses indicated for the model with parameters freely estimated a $\chi^{2}(664)=1345.98$ $(p<.001), \mathrm{CFI}=.920$, and RMSEA $=.035$ (C.I. $=.032-$ .038 ), and for the model with constrained factor loadings a $\chi^{2}(686)=1379.35(p<.001), \mathrm{CFI}=.918$, and RMSEA $=.035$ $(\mathrm{CI}=.032-.037)$. The difference between the CFI indices $(\triangle C F I)$ does not exceed .01 , so it can be stated that both the factor structure of the scale as the factor weights of the items are similar between boys and girls.

\section{Discussion}

This study aimed to present the process of adapting the CRC Scale for Brazilian children, as well as some of its psychometric properties in this sample. In the CRC adaptation process, two items were excluded, which increased Cronbach's alpha. In the original scale, both items belong to the negative religious coping dimension. However, they do not represent an insecure relationship with God, tension between members of a religious community, a pessimistic view of the world or a spiritual discomfort that would be the theoretical indication of negative religious coping (Pargament et al., 1998). Also in this process, some specific religious terms were inserted into or modified in the scale, with the aim to make the instrument more inclusive to different religious denominations/beliefs.

Regarding the psychometric properties evaluation, the factor analyses confirmed that religious coping strategies can be classified into two dimensions for this sample. Although there is little empirical evidence of the role religious beliefs play in how children cope with a stressor, this result 
corroborates the works of Benore et al. (2008) and Dupre (2008) on the CRC scale. The two-factor model suggested from studies with adults and adolescents (Al-Hadethe et al., 2014; Pargament et al., 2000) enables the investigation of the relationships of these dimensions with other psychological constructs.

The fact that the two dimensions were significantly and positively correlated suggests that children who use higher levels of PRC also tend to use more NRC strategies. A similar result was found by Dupre, which states that this may indicate that children who use religious coping strategies do it without distinguishing or selecting aspects that may be more beneficial in psychosocial terms.

Although the two-factor solution has been shown to be possible, the principal components analysis conducted separately with each dimension, as well as the confirmatory factor analysis, demonstrated the identification of other subscales underlying the construct of religious coping. These subscales corroborate data found by Panzini and Bandeira (2005) in the Spiritual/Religious Coping Scale adapted for Brazilian adults, and contributes to a more specific understanding of the religious coping strategies objectives, in addition to being consistent with theoretical understanding, and constructs purposes. Regarding the internal consistency of the scale, in both solutions, all factors showed a level of at least moderate reliability (above .60). The three factors of NRC dimension had the lowest alphas. The lower reliability of the negative factor was also indicated by other studies on the scale (Benore et al., 2008; Dupre, 2008).

The six factors that compose the final model showed specific aspects of the use of religious coping, but the need for adding of errors covariances indicates that these items also have aspects that may be similar and that further studies may suggest changes in terms of items composition, so as to improve the fit. Regarding this aspect, it can be stated that when seeking to evaluate the many possible strategies, it is assumed there is possibility of an overlap of the items in terms of theoretical significance. Carver et al. (1989) state that a weakness in instruments that assess coping in general is the difficulty of including all of the specific domains theoretically interesting. Although religious coping measures must access a wide range of strategies, it is not feasible to develop scales that reflect coping methods at all times and in all religious groups in a single instrument. It is understood that it is possible to access the strategies that are applicable to most of the population, and in the case of CRC, from the JudeoChristian traditions (Pargament et al., 2000).

The results obtained suggest the use of CRC Scale is indicated with six factors for greater specification of the coping strategies used by children. It is highlighted that the multigroup confirmatory factor analysis performed allows us to affirm that the scale has the same functioning for boys and girls in terms of factor structure and importance of items.

The possibility of carrying out the research with a large sample is a positive factor of this study, as most studies of religious coping in children are conducted with small samples (Benore et al., 2008; Mahoney et al.,
2006). One limitation of this study is that the participants consisted of a convenience sample, which means that the findings may not be generalized. Nevertheless, the sample was quite heterogeneous, presenting a balance among children based on characteristics of sex, public and private schools, as well as from different contexts (the capital and inner cities of the state). It is also noted that participants were only children from the Rio Grande do Sul State. Considering the importance of context in the coping process, it is suggested that the CRC be applied in other Brazilian' samples, both for checking the function of the scale and to develop knowledge of the religious coping strategies used by children. In this light, future studies with this instrument are needed to verify its functioning in other samples and to provide content and incremental validity.

It is noteworthy that studies on religious coping in childhood are still very limited. As stated by Dupre (2008), there is no exact consensus, for example, about the behaviors, thoughts, and interpersonal relationships involved in the use of religious coping strategies. Thus, studies with children on this topic are still very much based on the adult literature. Therefore, we believe that this study contributes to this field of knowledge, but is not conclusive, since many steps still need to be taken in understanding the process of children's religious coping.

Previous studies indicate the contribution of spirituality and religiosity to well-being in young people (Casas et al., 2015; Holder, Coleman, Krupa, \& Krupa, 2016; Sarriera et al., 2014). This study intends to contribute to the research in this area, since the availability of an instrument that assesses religious coping may allow the investigation of possible relationships with other constructs and the impact on health and quality of life in the childhood. It also allows for research with larger samples in different populations and contexts. One major benefit of scientifically examining specific religious coping is that such processes better predict an individual overall adjustment to life stressors and the consequences of negative life experiences than do global indicators of religious involvement, such as frequency of religious attendance, religious affiliation, or overall importance of religion in one's life. Also, as stated in Cotton et al. (2010), with improved measurement it is possible to develop in a more targeted and precise way interventions with programs that include religious and spiritual factors aimed at improving health.

\section{References}

Al-Hadethe, A., Hunt, N., Thomas, S., \& Al-Qaysi, A. (2014). Cross-cultural validation and psychometric properties of the Arabic Brief Religious Coping Scale (A-BRCS). Journal of Religion and Health, 55(1), 16-25. doi:10.1007/ s10943-014-9963-7

Benore, E., Pargament, K. I., \& Pendleton, S. (2008). An initial examination of religious coping in children with asthma. International Journal for the Psychology of Religion, 18(4), 267-290. doi:10.1080/10508610802229197 
Bjorck, J. P., Braese, R. W., Tadie, J. T., \& Gililland, D. D. (2010). The Adolescent Religious Coping Scale: Development, validation, and cross-validation. Journal of Child and Family Studies, 19(3), 343-359. doi:10.1007/ s10826-009-9305-7

Borsa, J. C., Damásio, B. F., \& Bandeira, D. R. (2012). Cross-cultural adaptation and validation of psychological instruments: Some considerations. Paidéia (Ribeirão Preto), 22(53), 423-432. doi:10.1590/S0103$863 \times 2012000300014$

Carver, C. S., Scheier, M. F., \& Weintraub, J. K. (1989). Assessing coping strategies: A theoretically based approach. Journal of Personality and Social Psychology, 56(2), 267-283. doi:10.1037/0022-3514.56.2.267

Casas, F., Sarriera, J. C., Alfaro, J., González, M., Bedin, L., Abs, D., ... Valdenegro, B. (2015). Reconsidering life domains that contribute to subjective well-being among adolescents with data from three countries. Journal of Happiness Studies, 16(2), 491-513. doi:10.1007/s10902014-9520-9

Compas, B. E., Connor-Smith, J. K., Saltzman, H., Thomsen, A. H., \& Wadsworth, M. E. (2001). Coping with stress during childhood and adolescence: Problems, progress, and potential in theory and research. Psychological Bulletin, 127(1), 87-127. doi:10.1037/0033-2909.127.1.87

Cotton, S., Grossoehm, D., \& McGrady, M. E. (2012). Religious coping and the use of prayer in children with sickle cell disease. Pediatric Blood \& Cancer, 58(2), 244249. doi:10.1002/pbc. 23038

Cotton, S., McGrady, M. E., \& Rosenthal, S. L. (2010). Measurement of religiosity/spirituality in adolescent health outcomes research: Trends and recommendations. Journal of Religion and Health, 49(4), 414-444. doi:10.1007/s10943-010-9324-0

Dupre, E. P. (2008). The impact of religious forms of coping for low-income African American middle school children (Doctoral dissertation). Available from ProQuest Dissertations and Theses database (UMI No. 3332365).

Hair, J. F., Jr., Black, W. C., Babin, B. J., Anderson, R. E., \& Tatham, R. L. (2009). Análise multivariada de dados [Multivariate data analysis] (6a ed.). Porto Alegre, RS: Bookman.

Holder, M. D., Coleman, B., Krupa, T., \& Krupa, E. (2016). Well-being's relation to religiosity and spirituality in children and adolescents in Zambia. Journal of Happiness Studies, 17(3), 1235-1253. doi:10.1007/s10902-015-9640-x

Lazarus, R. S., \& Folkman, S. (1987). Transactional theory and research on emotions and coping. European Journal of Personality, 1(3), 141-169. doi:10.1002/per.2410010304

Mahoney, A., Pendleton, S., \& Ihrke, H. (2006). Religious coping by children and adolescents: Unexplored territory in the realm of spiritual development. In E. C. Roehlkepartain, P. E. King, L. Wagener, \& P. L. Benson (Eds.), The handbook of spiritual development in childhood and adolescence (pp. 341-354). Thousand Oaks, CA: Sage.
Milfont, T. L., \& Fischer, R. (2010). Testing measurement invariance across groups: Applications in cross-cultural research. International Journal of Psychological Research, 3(1), 111-121.

Noh, H., Chang, E., Jang, Y., Lee, J. H., \& Lee, S. M. (2015). Suppressor effects of positive and negative religious coping on academic burnout among Korean middle school students. Journal of Religion and Health, 55(1), 135-146. doi:10.1007/s10943-015-0007-8

Panzini, R. G., \& Bandeira, D. R. (2005). Escala de Coping Religioso-Espiritual (Escala CRE): Elaboração e validação de construto [Spiritual/religious coping scale (SRCOPE Scale): Elaboration and construct validation]. Psicologia em Estudo, 10(3), 507-516. doi:10.1590/ S1413-73722005000300019

Panzini, R. G., \& Bandeira, D. R. (2007). Coping (enfrentamento) religioso/espiritual [Spiritual/religious coping]. Revista de Psiquiatria Clínica, 34(Supl. 1), 126135. doi:10.1590/S0101-60832007000700016

Pargament, K. I. (1997). The psychology of religion and coping: Theory, research and practice. New York, NY: Guilford.

Pargament, K. I., Koenig, H. G., \& Perez, L. M. (2000). The many methods of religious coping: Development and initial validation of the RCOPE. Journal of Clinical Psychology, 56(4), 519-543. doi:10.1002/(SICI)10974679(200004)56:4<519::AID-JCLP6>3.0.CO;2-1

Pargament, K. I., Smith, B. W., Koenig, H. G., \& Perez, L. (1998). Patterns of positive and negative religious coping with major life stressors. Journal for the Scientific Study of Religion, 37(4), 710-724. doi:10.2307/1388152

Pendleton, S. M., Cavalli, K. S., Pargament, K. I., \& Nasr, S. Z. (2002). Religious/spiritual coping in childhood cystic fibrosis: A qualitative study. Pediatrics, 109(1), E8. doi:10.1542/peds.109.1.e8

Renani, H. A., Hajinejad, F., Idani, E., \& Ravanipour, M. (2014). Children with asthma and their families' viewpoints on spiritual and psychological resources in adaptation with the disease. Journal of Religion and Health, 53(4), 1176-1189. doi:10.1007/s10943-013-9782-2

Reynolds, N., Mrug, S., Hensler, M., Guion, K., \& MadanSwain, A. (2014). Spiritual coping and adjustment in adolescents with chronic illness: A 2-year prospective study. Journal of Pediatric Psychology, 39(5), 542-551. doi:10.1093/jpepsy/jsu011

Ryan-Wenger, N. A., Sharrer, V. W., \& Campbell, K. K. (2005). Changes in children's stressors over the past 30 years. Pediatric Nursing, 31(4), 282-288, 291.

Sarriera, J. C., Casas, F., Alfaro, J., Bedin, L., Strelhow, M. R. W., Abs, D., ... Oyarzún, D. (2014). Psychometric properties of the personal wellbeing index in Brazilian and Chilean adolescents including spirituality and religion. Psicologia: Reflexão e Crítica, 27(4), 710-719. doi:10.1590/1678-7153.201427411 
Miriam Raquel Wachholz Strelhow is a Ph.D. candidate in the Graduate Program in Psychology at Universidade Federal do Rio Grande do Sul.

Livia Maria Bedin is an invited researcher at Universidade Federal do Rio Grande do Sul

Jorge Castellá Sarriera is a Professor in the Psychology Institute of the Universidade Federal do Rio Grande do Sul.

Received: Sep. 22, 2015

1st Revision: Feb. 28, 2016

Approved: May 10, 2016

How to cite this article:

Strelhow, M. R. W., Bedin, L. M., \& Sarriera, J. C. (2017). Children's Religious Coping Scale: Adaptation and psychometric properties. Paidéia (Ribeirão Preto), 27(66), 107-116. doi: 10.1590/1982-43272766201713 